\title{
Regulation of transforming growth factor $\beta$-mediated epithelial-mesenchymal transition of lens epithelial cells by c-Src kinase under high glucose conditions
}

\author{
ZHI-HUA HAN, FANG WANG, FU-LEI WANG, QI LIU and JIAN ZHOU \\ Department of Ophthalmology, Xijing Hospital, Fourth Military Medical University, Xi'an, Shaanxi 710032, P.R. China
}

Received August 2, 2017; Accepted February 22, 2018

DOI: $10.3892 /$ etm.2018.6348

\begin{abstract}
Recent studies have reported that high glucose (HG) conditions may contribute to the acceleration of renal cell apoptosis and renal fibrosis by inducing epithelial-mesenchymal transition (EMT) of tubular epithelial cells, in which c-Src kinase and transforming growth factor (TGF)- $\beta$ are key modulators. In the present study, the roles of c-Src kinase and TGF- $\beta$ in EMT of lens epithelial cells (LECs) under HG conditions were investigated. Results indicated human lens epithelial B3 (HLE-B3) cells under HG conditions exhibited significantly increased protein expression levels of phosphorylated $\mathrm{c}-\mathrm{Src}\left(\mathrm{p}-\mathrm{Src}^{418}\right)(\mathrm{P}<0.05)$ and secreted a significantly increased amount of TGF- $\beta$ compared with HLE-B3 cells under normal glucose conditions $(\mathrm{P}<0.05)$. Notably the $\mathrm{c}-\mathrm{Src}$ inhibitor PP1 and the activin receptor-like kinase 5 (ALK5) inhibitor SB431542 suppressed EMT of HLE-B3 cells. Results indicated that PP1 significantly inhibited the activities of c-Src and ALK5 and the secretion of TGF- $\beta$, whereas SB431542 only significantly downregulated the protein expression levels and secretion of TGF- $\beta(\mathrm{P}<0.05)$. Following c-Src knockdown, the protein expression levels of $\mathrm{p}-\mathrm{Src}^{418}$, ALK5 and TGF- $\beta$ were significantly decreased, the secretion of TGF- $\beta$ was significantly suppressed (both $\mathrm{P}<0.05$ ) and EMT was decreased in HLE-B3 cells. These results suggest that $c-S r c$ and TGF- $\beta$ may promote EMT of LECs under HG conditions, with c-Src as the upstream regulatory molecule. Thus, the signal axis of c-Src/TGF- $\beta$ in EMT of LECs may be a potential novel therapeutic target for the prevention of diabetic subcapsular cataract.
\end{abstract}

\section{Introduction}

Patients with diabetes mellitus typically develop irreversible renal and ocular tissue impairments due to the high levels of

Correspondence to: Dr Jian Zhou, Department of Ophthalmology, Xijing Hospital, Fourth Military Medical University, 169 Changle West Road, Xi'an, Shaanxi 710032, P.R. China

E-mail: zhoojian@yeah.net

Key words: epithelial-mesenchymal transition, lens epithelial cells, c-Src kinase, transforming growth factor- $\beta$, high glucose blood glucose $(1,2)$. Diabetic cataract is one of the major ocular complications of diabetes mellitus and subcapsular cataract is considered the distinctive phenotype (3). Notably, a previous study demonstrated that human lens epithelial cells (LECs) are involved in modifications of proliferation and apoptosis in diabetic subcapsular cataract in an aldose reductase 2 (ALR2) transgenic mouse model (4). It has been reported that a number of aberrant nucleated cells assemble underneath the posterior subcapsular region in experimentally diabetic mice (5). However, the exact mechanism in diabetic cataract formation remains unclear.

Under physiological conditions, LECs are located in the less proliferative center zone or the mitotically active germinative zone of the lens. These LECs regulate the majority of the homeostatic functions of the lens, including its growth and differentiation, repair of damage and maintenance of lens transparency (6). However, under pathological conditions, LECs may promote the emergence of various types of cataracts, including posterior capsule opacity (PCO), anterior subcapsular cataract (ASC) and diabetic cataract (7).

Transforming growth factor (TGF)- $\beta$ is a pleiotropic growth factor that controls cell growth, proliferation and migration, morphological plasticity and epithelial-mesenchymal transition (EMT) in tumor cells and specific epithelial cells (8-11). Furthermore, TGF- $\beta$ exerts its biological effects through two membrane-bound receptors, designated type II and activin receptor-like kinase 5 (ALK5) (6). In the TGF- $\beta$ family, TGF- $\beta 1$ and TGF- $\beta 2$ are expressed abundantly in the human lens and ocular media (12), and are considered key factors that regulate LEC proliferation, migration and EMT in ASC and PCO $(13,14)$. Pathological studies regarding posterior subcapsular cataract (PSC) have indicated that various abnormal nucleated cells and the extracellular matrix accumulate underneath the capsule, resulting in transformation of the epithelial cell phenotype into fibroblastic cells (13-15). These studies suggested EMT of LECs may be an important initial step in the development of PCO and ASC, in which TGF- $\beta$ is a major inducing factor. Du et al (16) studied the mechanism of high glucose (HG)-induced lens opacity accompanied by lens fibrosis in mice. The study reported that the TGF- $\beta 2$ /phosphoinositide 3-kinase/protein kinase B axis served an important role in HG-induced EMT of ex vivo human LECs and the inhibition of TGF- $\beta$ delayed the EMT of LECs. Kim et al (17) identified that aldose reductase (AR) and 
TGF- $\beta$ exerted vital actions in a rat diabetic cataract model. The study indicated that the inhibition of AR resulted in the decrease of mRNA expression levels of TGF- $\beta$ and fibronectin (FN) in HG-induced ex vivo human LECs. In another study, Kim et al (18) reported that the expression levels of TGF- $\beta$ and FN were increased in HG-induced ex vivo human LECs and the expression levels of TGF- $\beta 2$, Smad2/3, p38 mitogen-activated protein kinase (MAPK) and FN were decreased when the inhibitor KIOM-79 was applied. The results suggest that TGF- $\beta 2 / \mathrm{p} 38 \mathrm{MAPK}$ and TGF- $\beta 2 / \mathrm{Smad} 2 / 3$ signaling pathways may serve key roles in EMT of LECs.

$\mathrm{Lu}$ et al (19) reported that rat lenses cultured in HG conditions exhibited increased expression levels of TGF- $\beta$, E-cadherin and $\alpha$-smooth muscle actin (SMA). These results suggest that TGF- $\beta$ may be a key molecule in EMT of HG-induced LECs and diabetic cataract. However, it remains unclear whether EMT of LECs is involved in PSC.

$\mathrm{c}$-Src kinase, converting into $\mathrm{p}-\mathrm{Src}^{418}$ when activated, is a non-receptor intracellular tyrosine kinase that mediates a variety of cellular responses (20). c-Src may be activated by oxidative stress, osmotic stress, ultraviolet radiation and inflammation, which are associated with cataract formation (21-23). In various types of tumor cells, activated c-Src serves a principal role in regulating EMT properties, cell adhesion, proliferation and migration (24-27) and tumor metastasis $(28,29)$. Notably, in the ocular media, activated c-Src is considered a predominant factor in the formation of cortical cataracts $(30,31)$. Previously, it was revealed that activated c-Src mediated the EMT of LECs in normal culture medium, resulting in the occurrence of $\mathrm{PCO}$ in vitro (32).

In the present study, HLE-B3 cells were employed in vitro to investigate the roles of $\mathrm{c}-\mathrm{Src}$ and TGF- $\beta$ in the EMT of LECs. Furthermore, the association between c-Src and TGF- $\beta$ was assessed.

\section{Materials and methods}

Cell culture, reagents and treatments. Immortalized human lens epithelial cells (HLE-B3) cells were obtained from Dr Zhang Wei at the Beijing Institute of Ophthalmology (Beijing, China). HLE-B3 cells were maintained in Dulbecco's modified Eagle medium (DMEM) supplemented with $10 \%$ fetal bovine serum (HyClone; GE Healthcare Life Sciences, Logan, Utah, USA), penicillin (100 units/ml) and streptomycin $(100 \mu \mathrm{g} / \mathrm{ml})$. All cells were maintained at $37^{\circ} \mathrm{C}$ in a humidified incubator containing $5 \% \mathrm{CO}_{2}$. Cells were treated with $0.25 \%$ trypsin- $0.02 \%$ EDTA solution and passaged at $75-80 \%$ confluence.

Stock solutions of PP1, a c-Src inhibitor, and SB431542, an ALK5 inhibitor, (Enzo Life Sciences, Inc., Farmingdale, NY, USA) were prepared in dimethyl sulfoxide and diluted with cell culture media to obtain a final concentration of $10 \mu \mathrm{mol} / \mathrm{l}$. Antibodies against c-Src (cat. no. 2123), E-cadherin (cat. no. 3195), $\beta$-tubulin (cat. no. 2128) and $\beta$-actin (cat. no. 4970) were obtained from Cell Signaling Technology, Inc. (Danvers, MA, USA). Antibodies against TGF- $\beta 1$ (cat. no. ab92486), p-Src ${ }^{418}$ (cat. no. ab4816), $\alpha$-SMA (cat. no. ab5694), ALK5 (cat. no. ab31013) and GAPDH (cat. no. ab181602) were obtained from Abcam (Cambridge, MA, USA). Anti-TGF- $\beta 2$ antibody (cat. no. ABE586) was obtained from EMD Millipore (Bedford, MA, USA).
A preliminary study was performed to optimize the time and glucose concentration for subsequent experiments. HLE-B3 cells were subsequently divided into three groups: HG DMEM (glucose, $35.5 \mathrm{mM}$ ), HG DMEM with PP1 (10 $\mu \mathrm{mol} / \mathrm{l})$ and HG DMEM with SB431542 (10 $\mu \mathrm{mol} / \mathrm{l})$. The glucose concentration for the normal glucose (NG) group was $5.5 \mathrm{mM}$. The time-dependent effects were measured at $0,3,6$ and $12 \mathrm{~h}$ for further experiments. The HLE-B3 cells in exponential growth phase were seeded at a cell density of $1 \times 10^{5}$ cells $/ \mathrm{ml}$, cultured at $37^{\circ} \mathrm{C}, 5 \% \mathrm{CO}_{2}$ and then assessed at 0,3 and $6 \mathrm{~h}$.

Short hairpin (sh)RNA knockdown assay. shRNA for human c-Src (GenBank no. NM: 005417) and random control lentiviral plasmid (pLKO.1-puro Control Vector) were obtained from GenePharma (GenePharma Co. Ltd, Beijing, China). The human HLE-B3 cells were cultured in the $60 \mathrm{~mm}$ diameter culture dish under $37^{\circ} \mathrm{C}, 5 \% \mathrm{CO}_{2}$ condition. When cells growth covered $50-60 \%$ of the dish, the cells were transfected with $5 \mu \mathrm{g}$ shRNA-c-Src or $5 \mu \mathrm{g}$ shRNA-vector using Lipofectamine 2000 transfection reagent (Invitrogen; Thermo Fisher Scientific, Inc., Waltham, MA, USA) according to the manufacturer's recommendations. Following $72 \mathrm{~h}$ of incubation, transfection efficiency was measured by determining the green fluorescent protein expression ratio via fluorescence microscopy (Olympus BX53; Olympus Corporation, Tokyo, Japan; data not shown).

In c-Src knockdown experiments, $5 \times 10^{6}$ cells/ml HLE-B3 cells were divided into two groups: shRNA-vector and shRNA-c-Src. Cells were cultured in HG DMEM (35.5 mM) for a total of $12 \mathrm{~h}$, and the time-dependent effects were monitored at 0,3, 6, 9 and $12 \mathrm{~h}$. The knockdown of c-Src was confirmed via western blot analysis.

Western blot analysis. Total protein in HLE-B3 cells was extracted using radioimmunoprecipitation assay lysis buffer with protease inhibitor cocktail set1 (cat. no. 539131) and phosphatase inhibitor cocktail set V (cat. no. 524629; all EMD Millipore). Protein concentration was determined using BCA protein assay reagent (Beyotime Institute of Biotechnology, Shanghai, China). Proteins (30 $\mu \mathrm{g} / \mathrm{lane})$ were separated using $10 \%$ SDS-PAGE and electrophoretically transferred onto nitrocellulose filter membranes (EMD Millipore). Membranes were blocked in $4{ }^{\circ} \mathrm{C}$ overnight with $5 \%$ non-fat milk and incubated with various primary antibodies, including rabbit anti-c-Src monoclonal antibody $(1: 10,000)$, rabbit anti-p-Src ${ }^{418}$ monoclonal antibody $(1: 1,000)$, rabbit anti-TGF- $\beta 1$ polyclonal antibody (1:100), rabbit anti-TGF- $\beta 2$ polyclonal antibody $(1: 1,000)$, rabbit anti-E-cadherin polyclonal antibody $(1: 1,000)$, rabbit anti- $\alpha$-SMA polyclonal antibody $(1: 1,000)$, rabbit anti-ALK5 polyclonal antibody (1:200), rabbit anti- $\beta$-actin monoclonal antibody $(1: 1,000)$, rabbit anti- $\beta$-tubulin monoclonal antibody $(1: 1,000)$ and rabbit anti-GAPDH monoclonal antibody $(1: 10,000)$ at $4^{\circ} \mathrm{C}$ for $18 \mathrm{~h}$. Following $2 \mathrm{~h}$ incubation at room temperature with horseradish peroxidase-conjugated secondary antibody (1:1,000; cat. no. 7074; Cell Signaling Technology, Inc.), the protein bands were quantified using a Bio-Rad chemiluminescent gel imaging system and standardized to $\beta$-actin, $\beta$-tubulin or GAPDH protein expression using Image $\mathrm{Lab}^{\mathrm{TM}}$ software (version 6.0; both Bio-Rad Laboratories, Inc., Hercules, CA, USA). 
A

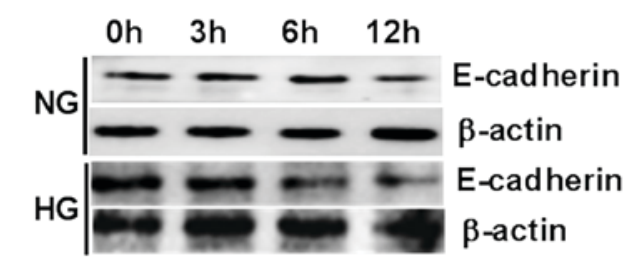

B

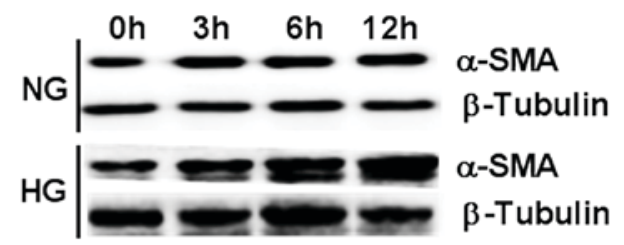

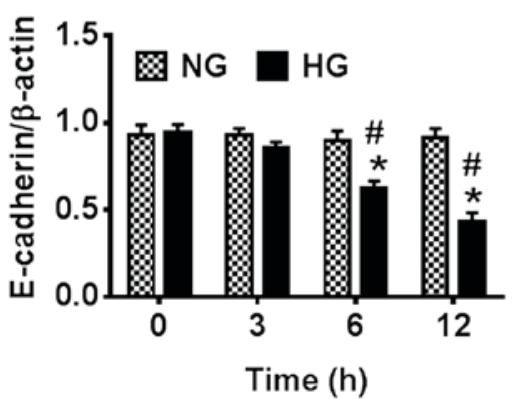

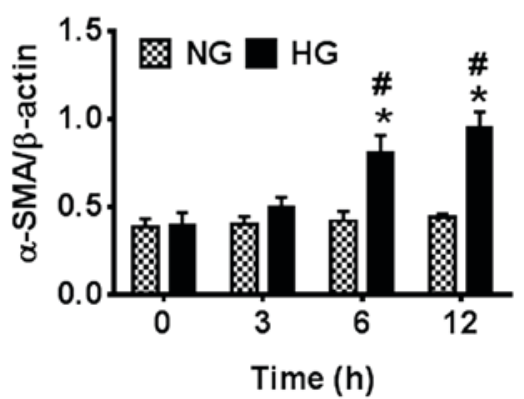

Figure 1. Effects of NG $(5.5 \mathrm{mM})$ and $\mathrm{HG}(35.5 \mathrm{mM})$ conditions on the protein expression levels of E-cadherin and $\alpha$-SMA in human lens epithelial B3 cells at 0 to $12 \mathrm{~h}$. The protein expression levels of (A) E-cadherin and (B) $\alpha$-SMA were determined using western blot analysis. Data are presented as the mean \pm standard deviation. ${ }^{*} \mathrm{P}<0.05$ vs. $0 \mathrm{~h}$ in the same group; ${ }^{\#} \mathrm{P}<0.05$ vs. $\mathrm{NG}$ group at the same time point. NG, normal glucose; HG, high glucose; $\alpha-\mathrm{SMA}$, $\alpha$-smooth muscle actin.

Determination of TGF- $\beta 1$ and TGF- $\beta 2$ secretion using ELISA. An ELISA kit (eBioscience; Thermo Fisher Scientific, Inc.) was employed to evaluate the secretion of TGF- $\beta 1$ (cat. no. BMS249-4) and TGF- $\beta 2$ (cat. no. BMS254) according to the manufacturer's protocol. Three samples of each group were examined.

Statistical analysis. All data were analyzed using SPSS statistical analysis software, version 16.0 (SPSS, Inc., Chicago, IL, USA). Data were expressed as the mean \pm standard deviation. For multiple group comparisons at different time points, statistical analysis was performed using repeated measures analysis of variance followed by Fisher's Least Significant Difference post hoc test. For groups at the same time point, the Student's t-test was used. $\mathrm{P}<0.05$ was considered to indicate a statistically significant difference.

\section{Results}

$H G$ conditions induce EMT of LECs. To investigate the effect of HG conditions on LECs, the protein expression levels of EMT marker protein E-cadherin and interstitial cell marker protein $\alpha$-SMA in HLE-B3 cells under HG and NG conditions were studied using western blot analysis. Results indicated that the protein expression levels of E-cadherin were marginally decreased whereas $\alpha$-SMA protein expression levels were marginally increased under normal glucose (NG) conditions between 0 to $12 \mathrm{~h}$. However, a time-dependent decrease in E-cadherin expression levels and a time-dependent increase in $\alpha$-SMA expression levels was indicated when HLE-B3 cells were exposed to $\mathrm{HG}$ conditions. The differences were significant at 6 and $12 \mathrm{~h}$ compared with $0 \mathrm{~h}$ under the same conditions $(\mathrm{P}<0.05)$. Additionally, results indicated that the protein expression levels of E-cadherin were significantly decreased whereas $\alpha$-SMA protein expression levels were significantly increased at 6 and $12 \mathrm{~h}$ in HLE-B3 cells under HG conditions compared with that in HLE-B3 cells under NG conditions at the same time points $(\mathrm{P}<0.05$; Fig. 1). These results suggested that LECs may slowly trans-differentiate into mesenchymal cells under HG conditions.

$H G$ conditions activate $c-S r c$. To further investigate the influence of $\mathrm{HG}$ conditions on the activity of c-Src, the protein expression levels of $\mathrm{p}-\mathrm{Src}^{418}$ were determined using western blot analysis under NG and HG conditions. The results demonstrated that there was little $\mathrm{p}-\mathrm{Src}^{418}$ expression observed following $12 \mathrm{~h}$ incubation under NG conditions. By contrast, the protein expression levels of $\mathrm{p}-\mathrm{Src}^{418}$ were elevated and reached a peak at $6 \mathrm{~h}$ of culture in $\mathrm{HG}$ conditions, which was followed by a decrease in $\mathrm{p}-\mathrm{Src}^{418}$ expression at $12 \mathrm{~h}$ (Fig. 2). Statistical analysis indicated that the protein expression levels of $\mathrm{p}-\mathrm{Src}^{418}$ were significantly increased under $\mathrm{HG}$ conditions at 3,6 and $12 \mathrm{~h}$ compared with at $0 \mathrm{~h}$ under HG conditions $(\mathrm{P}<0.05)$. Furthermore, the $\mathrm{p}-\mathrm{Src}^{418}$ protein expression levels of HLE-B3 cells at the corresponding time points in the HG conditions were significantly higher than those indicated under NG conditions $(\mathrm{P}<0.05)$, which suggested that the activation of c-Src was stimulated by $\mathrm{HG}$ conditions.

$H G$ conditions activate TGF- $\beta$. The influence of HG conditions on the activation of TGF- $\beta$ was observed using western blot analysis. There were no notable changes in the protein expression levels of TGF- $\beta 1$ and TGF- $\beta 2$ under NG conditions. However, under $\mathrm{HG}$ conditions the expression levels of TGF- $\beta 1$ and TGF- $\beta 2$ were marginally increased over $12 \mathrm{~h}$ (Fig. 3A and B). These findings suggested that $\mathrm{HG}$ conditions exerted little impact on the protein expression levels of TGF- $\beta 1$ and TGF- $\beta 2$.

The secretion of TGF- $\beta 1$ and TGF- $\beta 2$ was also measured under NG and HG conditions using ELISA. Results revealed that the secretion of TGF- $\beta 1$ and TGF- $\beta 2$ under NG conditions 

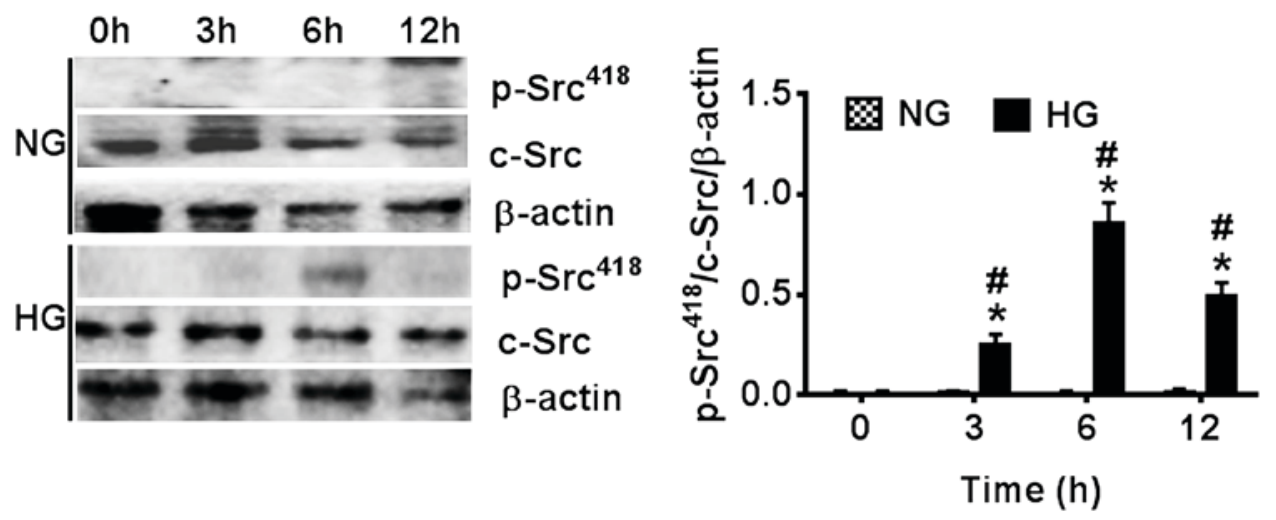

Figure 2. Effects of NG $(5.5 \mathrm{mM})$ and $\mathrm{HG}(35.5 \mathrm{mM})$ on the activity of c-Src in human lens epithelial B3 cells at 0 to 12 h. The protein expression levels of $\mathrm{p}-\mathrm{Src}^{418}$ were determined using western blot analysis. Data are presented as the mean \pm standard deviation. ${ }^{*} \mathrm{P}<0.05 \mathrm{vs} .0 \mathrm{~h}$ in the same group; ${ }^{\#} \mathrm{P}<0.05 \mathrm{vs}$. NG group at the same time point. NG, normal glucose; HG, high glucose.

was not significantly altered over $12 \mathrm{~h}$. However, a significant increase in the secretion of TGF- $\beta 1$ at 6 and $12 \mathrm{~h}$ and TGF- $\beta 2$ at 3, 6 and $12 \mathrm{~h}$ was observed under $\mathrm{HG}$ conditions compared with $0 \mathrm{~h}$ under the same conditions $(\mathrm{P}<0.05$; Fig. $3 \mathrm{C}$ and $\mathrm{D})$. Furthermore, significantly increased secretion of TGF- $\beta 1$ at 6 to $12 \mathrm{~h}$ and TGF- $\beta 2$ at 3,6 to $12 \mathrm{~h}$ was indicated under HG conditions compared with those indicated under NG conditions at the same time points $(\mathrm{P}<0.05)$.

Effect of $c$-Src and TGF- $\beta$ on EMT of LECs. To further investigate the regulatory effects of $\mathrm{c}-\mathrm{Src}$ and TGF- $\beta$ in EMT of LECs, SB431542 and PP1 were added to the HG media. PP1 was used to investigate the regulatory effect of c-Src on TGF- $\beta$, while SB431542 was used as the positive control. The protein expression levels of c-Src and TGF- $\beta$ were measured using western blot analysis and TGF- $\beta$ secretion was analyzed using ELISA. As indicated in Fig. 4, the protein expression levels of $\mathrm{p}-\mathrm{Src}^{418}$, TGF- $\beta 1$ and TGF- $\beta 2$ in HLE-B3 cells under HG conditions and PP1 were significantly decreased compared with those indicated in HLE-B3 cells under HG conditions alone $(\mathrm{P}<0.05)$. Notably, the secretion of TGF- $\beta 1$ and TGF- $\beta 2$ was significantly decreased in HLE-B3 cells under $\mathrm{HG}$ conditions and PP1 compared with cells under $\mathrm{HG}$ conditions alone at $6 \mathrm{~h}(\mathrm{P}<0.05$; Fig. 5). These findings suggest that active $\mathrm{c}-\mathrm{Src}$ promotes the activation of TGF- $\beta$. Under HG conditions, SB431542, which is an inhibitor of TGF- $\beta$, significantly downregulated the protein expression levels and secretion of TGF- $\beta 1$ and TGF- $\beta 2(\mathrm{P}<0.05)$ but exerted no significant effect on $\mathrm{p}-\mathrm{Src}^{418}$ expression levels compared with that in HLE-B3 cells under HG conditions alone (Figs. 4A-C and 5).

Effect of $c$-Src on the biological function of TGF- $\beta$ in EMT of LECs. The influence of c-Src on the biological function of TGF- $\beta$ was assessed by determining the activity of ALK5 using western blot analysis. The results revealed that the protein expression levels of ALK5 in HLE-B3 cells cultured under HG conditions with PP1 or SB431542 were significantly decreased compared with those in HLE-B3 cells under HG conditions alone at $6 \mathrm{~h}(\mathrm{P}<0.05$, Fig. 4D). This was consistent with the results obtained regarding TGF- $\beta 1$ and TGF- $\beta 2$ secretion in HLE-B3 cells cultured under HG conditions with
SB431542. The downregulation of ALK5 suggested that c-Src may influence the biological function of TGF- $\beta$.

$c$-Src and TGF- $\beta$ mediate EMT of LECs. The roles of c-Src and TGF- $\beta$ in EMT of HLE-B3 cells induced by HG conditions were determined by measuring the alterations of EMT protein markers E-cadherin and $\alpha$-SMA in HLE-B3 cells in the presence of PP1 or SB431542 using western blot analysis. The protein expression levels of E-cadherin in HLE-B3 cells under HG conditions were decreased in a time-dependent manner. However, HG conditions and PP1 or SB431542 increased the protein expression levels of E-cadherin in HLE-B3 cells compared with that in HLE-B3 cells cultured in $\mathrm{HG}$ conditions alone. This difference was statistically significant at $6 \mathrm{~h}(\mathrm{P}<0.05$; Fig. 4E). Notably, the protein expression levels of $\alpha$-SMA in HLE-B3 cells under HG conditions were increased in a time-dependent manner. However, the protein expression levels of $\alpha$-SMA were significantly decreased in HLE-B3 cells treated with PP1 or SB431542 under HG conditions compared with HLE-B3 cells under HG conditions alone at $6 \mathrm{~h}(\mathrm{P}<0.05$, Fig. $4 \mathrm{~F})$. These findings suggested that PP1 or SB431542 hindered the decrease of E-cadherin and the increase of $\alpha$-SMA, which suggested the role of $\mathrm{c}-\mathrm{Src}$ and TGF- $\beta$ in promoting EMT of LECs.

Influence of c-Src knockdown on TGF- $\beta$ and EMT of LECs. HLE-B3 cells transfected with shRNA-c-Src or shRNA-vector were exposed to $\mathrm{HG}$ conditions $(35.5 \mathrm{mM})$. As indicated in Fig. 6, the expression levels of $\mathrm{p}-\mathrm{Src}^{418}$ protein increased in a time-dependent manner up until $9 \mathrm{~h}$, after which the levels were decreased in the shRNA-vector group. In the shRNA-c-Src group, the $\mathrm{p}-\mathrm{Src}^{418}$ protein expression levels were significantly decreased compared with those indicated in the shRNA-vector group at the same time points $(\mathrm{P}<0.05$; Fig. $6 \mathrm{~A})$. The decreased expression level of $\mathrm{p}-\mathrm{Src}^{418}$ protein, instead of completely silenced $\mathrm{p}-\mathrm{Src}^{418}$, suggested that the knockdown of c-Src may not be completely successful.

The protein expression levels of TGF- $\beta 1$ and TGF- $\beta 2$ in shRNA-c-Src or shRNA-vector groups stimulated by $\mathrm{HG}$ conditions were observed using western blot analysis. In the shRNA-c-Src group, the expression levels of TGF- $\beta 1$ protein were increased in a time-dependent manner up until 

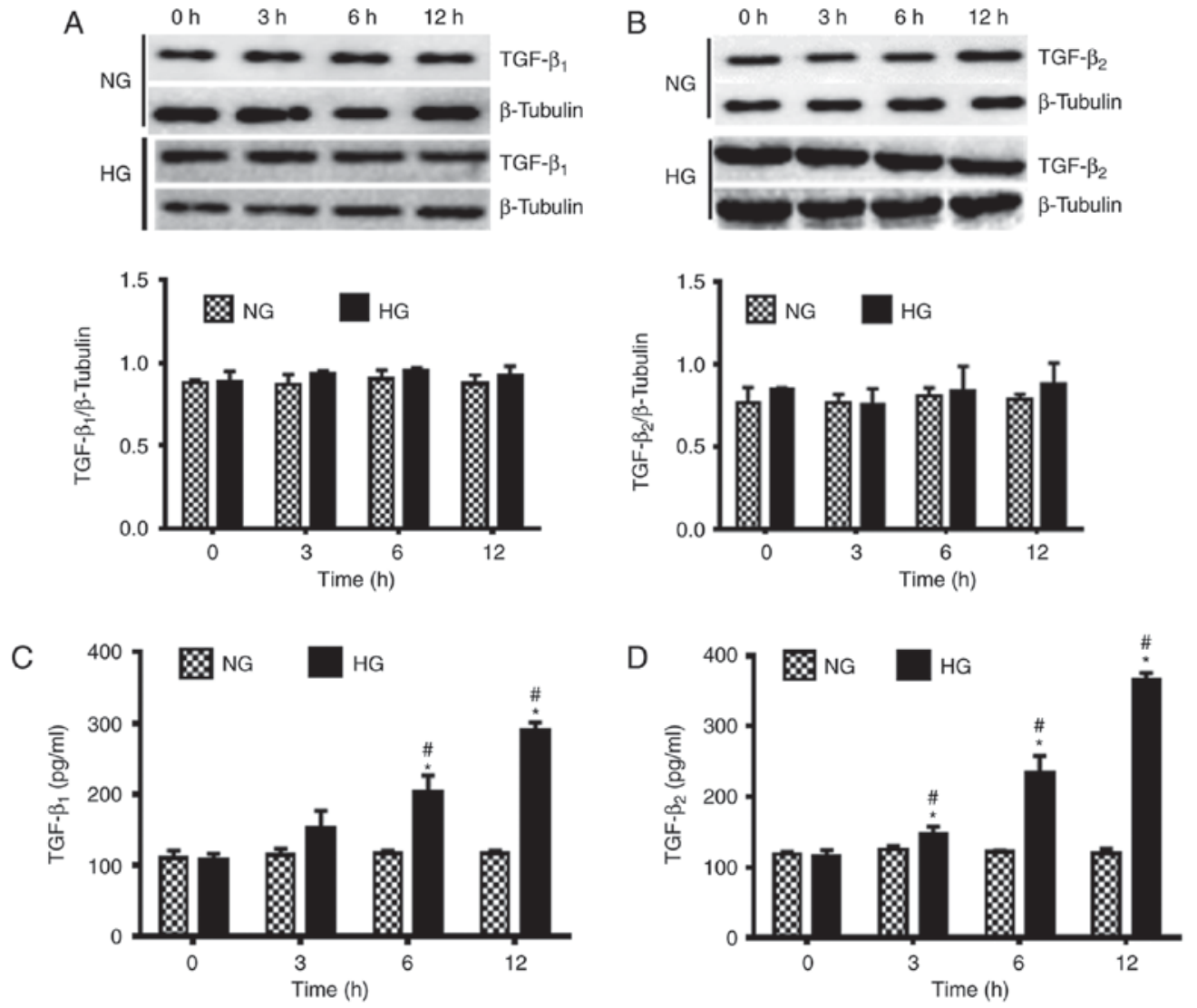

Figure 3. Effects of NG $(5.5 \mathrm{mM})$ and $\mathrm{HG}(35.5 \mathrm{mM})$ on the protein expression levels and secretion of TGF- $\beta 1$ and TGF- $\beta 2$ in human lens epithelial B3 cells at $0,3,6$ and $12 \mathrm{~h}$. Protein expression levels of (A) TGF- $\beta 1$ and (B) TGF- $\beta 2$ were determined using western blot analysis. The secretion of (C) TGF- $\beta 1$ and (D) TGF- $\beta 2$ was determined using ELISA. Data are presented as the mean \pm standard deviation. ${ }^{*} \mathrm{P}<0.05$ vs. $0 \mathrm{~h}$ in the same group; ${ }^{*} \mathrm{P}<0.05$ vs. NG group at the same time point. NG, normal glucose; HG, high glucose; TGF- $\beta$, transforming growth factor- $\beta$.

$9 \mathrm{~h}$, after which the expression levels were decreased. In the shRNA-c-Src group, TGF- $\beta 1$ protein expression levels significantly decrease compared with the shRNA-Vector group $(\mathrm{P}<0.05$; Fig. 6B). Notably, TGF- $\beta 2$ protein expression levels in the shRNA-c-Src and shRNA-vector groups were increased in a time-dependent manner up until $9 \mathrm{~h}$ after which the expression levels were decreased (Fig. 6A). However, the TGF- $\beta 2$ protein expression levels were significantly increased in the shRNA-vector group compared with the shRNA-c-Src group at all time points $(\mathrm{P}<0.05)$. These findings suggested that suppression of $\mathrm{c}-\mathrm{Src}$ significantly reduced the protein expression levels of TGF- $\beta$.

The secretion of HG-stimulated TGF- $\beta 1$ and TGF- $\beta 2$ proteins, were measured using ELISA in the shRNA-c-Src and shRNA-vector groups. In shRNA-c-Src and shRNA-vector groups, the secretion of TGF- $\beta 1$ and TGF- $\beta 2$ increased in a time-dependent manner without significant differences. Furthermore, the secretion of TGF- $\beta 1$ and TGF- $\beta 2$ was significantly decreased in the shRNA-c-Src group compared with that in the shRNA-vector group at all time points $(\mathrm{P}<0.05$; Fig. $6 \mathrm{~F}$ and $\mathrm{G}$ ), which suggested that the suppression of $\mathrm{c}-\mathrm{Src}$ effectively reduced the secretion of TGF- $\beta$.

Suppression of c-Src inhibits the biological function of TGF- $\beta$ in the EMT of LECs. To evaluate whether c-Src activity may influence the biological function of TGF- $\beta$, the expression levels of ALK5 stimulated by HG conditions in transfected
HLE-B3 cells were determined using western blot analysis. In the shRNA-vector and shRNA-c-Src groups, the protein expression levels of ALK5 were increased in a time-dependent manner. However, the protein expression levels of ALK5 were significantly decreased in the shRNA-c-Src group compared with the shRNA-vector group at 0 to $12 \mathrm{~h}(\mathrm{P}<0.05$; Fig. $6 \mathrm{C})$. These results suggested that $\mathrm{c}-\mathrm{Src}$ silencing inhibited the activity of ALK5, which is the downstream mediator of the TGF- $\beta$ signaling pathway.

Suppression of c-Src inhibits EMT of LECs. The influence of c-Src knockdown on EMT of LECs induced by HG conditions was investigated by evaluating the expression of EMT protein markers using western blot analysis. In the shRNA-vector and shRNA-c-Src groups, the protein expression levels of E-cadherin were decreased in a time-dependent manner. However, the expression levels of E-cadherin in the shRNA-vector group were significantly decreased compared with that in the shRNA-c-Src group at all time points $(\mathrm{P}<0.05$; Fig. 6D). Notably, the protein expression levels of $\alpha$-SMA were increased in the shRNA-vector and shRNA-c-Src groups in a time-dependent manner. Additionally, the protein expression levels of $\alpha$-SMA were significantly decreased in the shRNA-c-Src group compared with that in the shRNA-vector group at 0 to $12 \mathrm{~h}(\mathrm{P}<0.05$; Fig. $6 \mathrm{E})$. These results indicated that knockdown of c-Src may effectively inhibit EMT of LECs induced by HG conditions. 

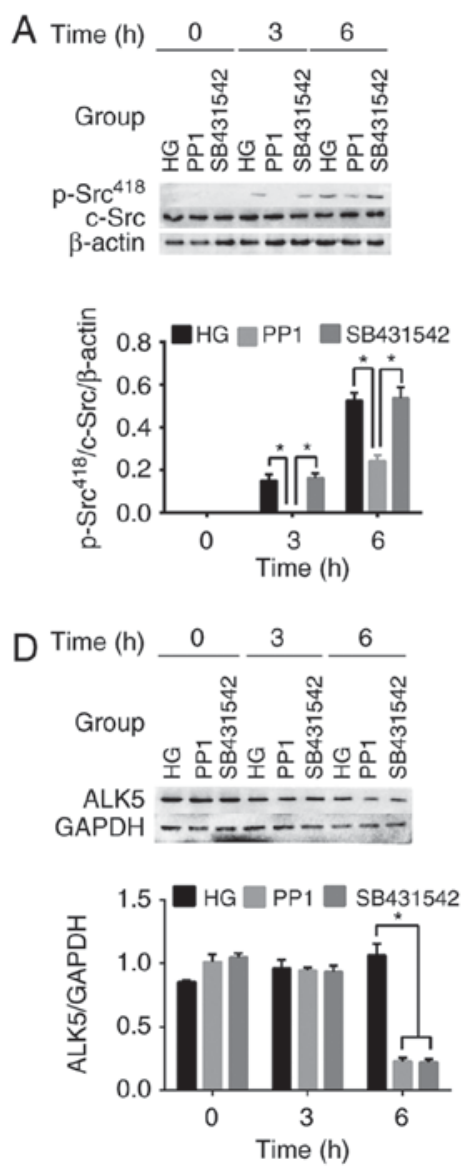
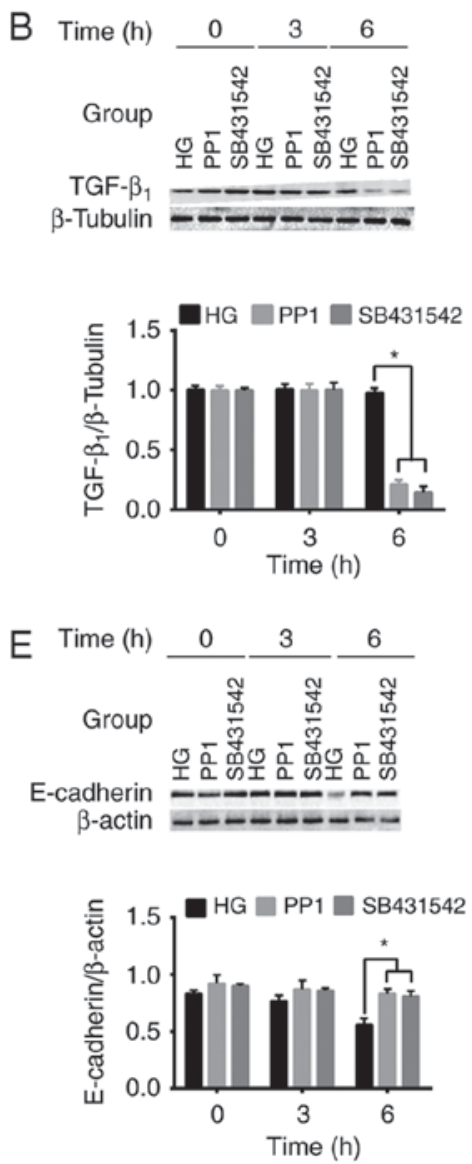
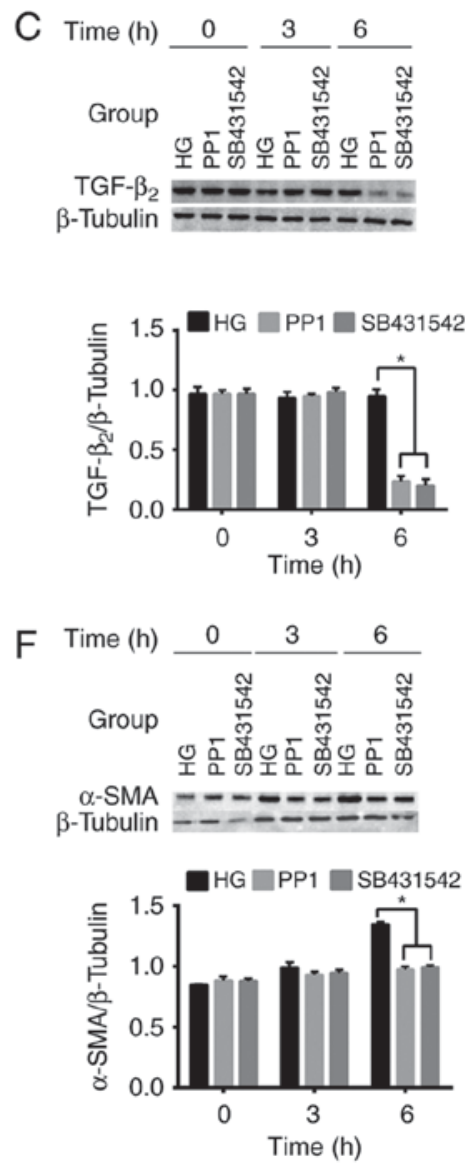

Figure 4. Effects of $10 \mu \mathrm{mol} / 1 \mathrm{c}$-Src inhibitor PP1 and $10 \mu \mathrm{mol} / 1$ ALK5 inhibitor SB431542 on the protein expression levels of p-Src ${ }^{418}$, TGF- $\beta 1$, TGF- $\beta 2$, ALK5, E-cadherin and $\alpha$-SMA under HG conditions at 0 to 6 h. Protein expression levels of (A) p-Src ${ }^{418}$, (B) TGF- $\beta 1$, (C) TGF- $\beta 2$, (D) ALK5, (E) E-cadherin and (F) $\alpha$-SMA were determined using western blot analysis. Data are presented as the mean \pm standard deviation. ${ }^{*} \mathrm{P}<0.05$ as indicated. HG, high glucose; TGF- $\beta$, transforming growth factor- $\beta ; \alpha$-SMA, $\alpha$-smooth muscle actin; ALK5, activin receptor-like kinase 5 .
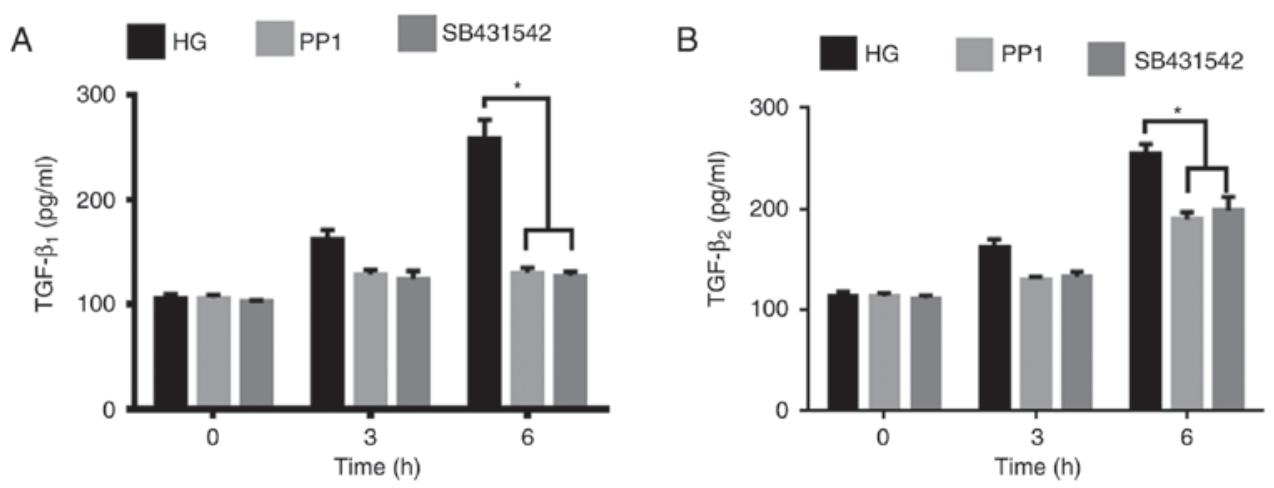

Figure 5. Effects of c-Src inhibitor PP1 and ALK5 inhibitor SB431542 on the secretion of TGF- $\beta 1$ and TGF- $\beta 2$ in human lens epithelial B3 cells under HG $(35.5 \mathrm{mM}$ ) conditions at 0 to $6 \mathrm{~h}$. Secretion of (A) TGF- $\beta 1$ and (B) TGF- $\beta 2$ was determined using ELISA. Data are presented as the mean \pm standard deviation. ${ }^{*} \mathrm{P}<0.05$ as indicated. HG, high glucose; TGF- $\beta$, transforming growth factor- $\beta$.

\section{Discussion}

EMT is a process by which epithelial cells lose their original characteristics and gain mesenchymal cell properties during specific physiological and pathological stages, including organ fibrosis $(33,34)$. Previous studies on the EMT of renal cells cultured in HG conditions ( 30 or $60 \mathrm{mM}$ ) demonstrated significant increases of $\alpha$-SMA and decreases of E-cadherin $(33,34)$. It was also reported that EMT is the primary factor in the pathogenesis of renal fibrosis, in which TGF- $\beta$ and c-Src are key inducing factors (35-38). Subcapsular cataract is a common type of diabetic cataract (39). Studies have revealed that a number of aberrant nucleated cells assemble underneath the posterior capsule in animal models of subcapsular cataract (13-15). However, at present, the exact mechanism and key trigger factors of diabetic subcapsular cataract remains unclear. In Rap39 transgenic animal models of diabetic cataract, the presence of $\alpha$-SMA was confirmed in 

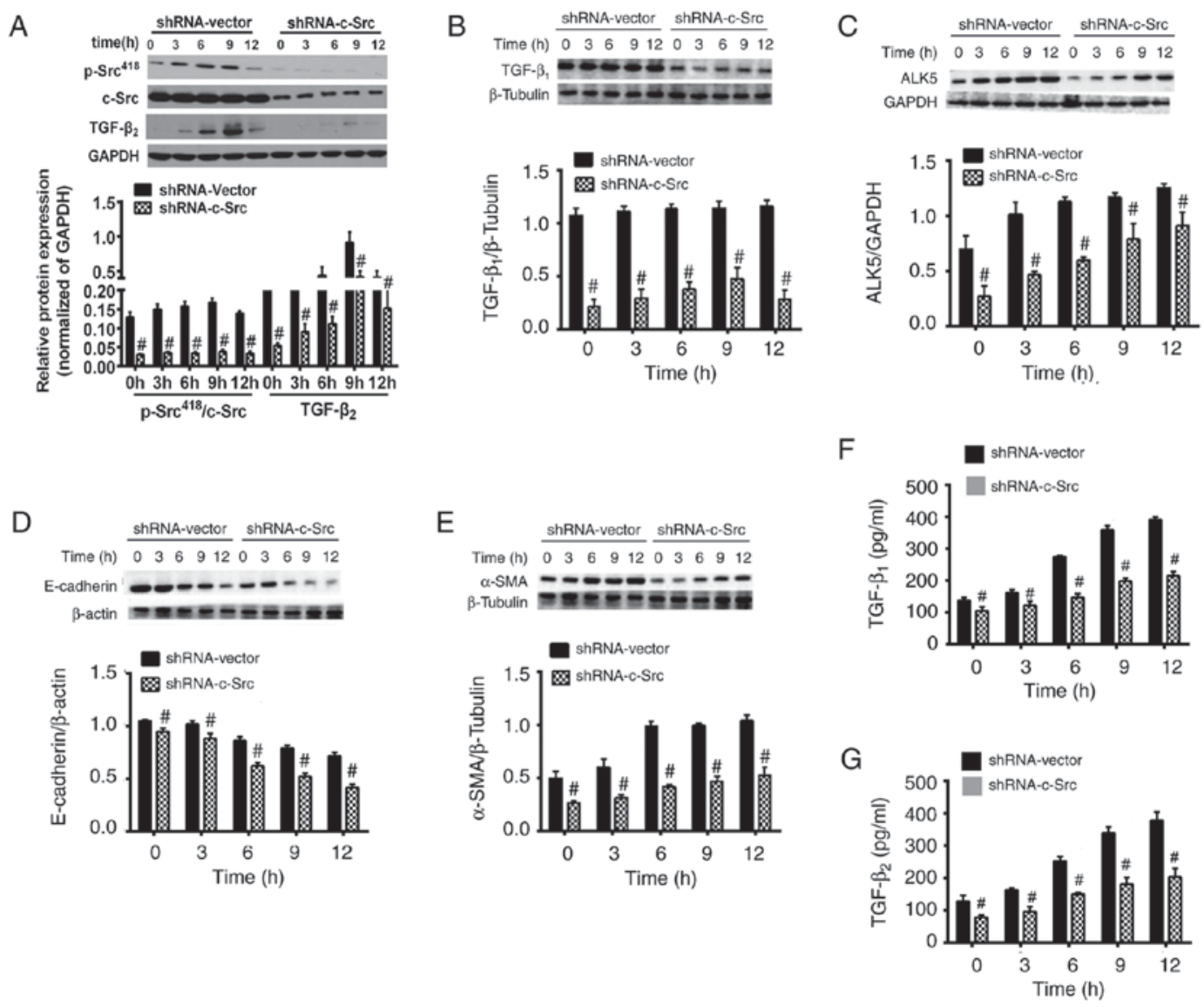

Figure 6. Effects of c-Src knockdown by shRNA on the protein expression levels of p-Scr ${ }^{418}$, TGF- $\beta 1$, TGF- $\beta 2$, ALK5, E-cadherin and $\alpha$-SMA in human lens epithelial B3 cells under HG conditions at 0 to 12 h. Protein expression levels of (A) p-Scr ${ }^{418}$ and TGF- $\beta 2$, (B) TGF- $\beta 1$, (C) ALK5, (D) E-cadherin and (E) $\alpha$-SMA were determined using western blot analysis. The secretion of (F) TGF- $\beta 1$ and (G) TGF- $\beta 2$ in human lens epithelial B3 cells under HG conditions was determined using ELISA. Data are presented as the mean \pm standard deviation. ${ }^{*} \mathrm{P}<0.05$ vs. shRNA-Vector group. HG, high glucose; TGF- $\beta$, transforming growth factor- $\beta$; shRNA, short hairpin RNA; $\alpha$-SMA, $\alpha$-smooth muscle actin; ALK5, activin receptor-like kinase 5 .

the muddy plaque underneath the anterior capsule of the lens in the early stage of cataract (4), suggesting that HG-induced EMT of LECs may be a key mechanism in animal models of diabetic cataract. The data obtained in the present study suggested a similar process in EMT of LECs under HG conditions $(35.5 \mathrm{mM})$ as the protein expression levels of E-cadherin were decreased and the protein expression levels of $\alpha$-SMA were increased over time.

The present study indicated that $\mathrm{HG}$ conditions contributed to the increased activity of TGF- $\beta$ and promoted the phosphorylation of c-Src. Glomerular mesangial cells incubated with $\mathrm{HG}$ (30 $\mathrm{mM}$ ) concentrations also demonstrated similar effects on the levels of $\mathrm{p}-\mathrm{Src}^{418}(40,41)$. Furthermore, it has been reported that exposure of A549 cells to HG $(25 \mathrm{mM})$ concentrations for $48 \mathrm{~h}$ resulted in increased activity of TGF- $\beta$ (42). This is in agreement with the present findings, which indicated that c-Src and TGF- $\beta$ were activated during EMT of LECs under HG conditions.

As c-Src and TGF- $\beta$ were concurrently activated in EMT of LECs, the roles of c-Src and TGF- $\beta$ in the EMT were further investigated in the present study. The results revealed that PP1 and SB431542 delayed the EMT progression in LECs induced by HG stimulation. Previous studies also suggested that PP1 and SB431542 suppressed the activities of $c-$ Src and TGF- $\beta$ following HG treatment in different cell phenotypes $(30,31,43,44)$. In addition, it was reported that activated c-Src promoted EMT and c-Src-specific inhibitors blocked EMT in renal tubular epithelial cells (45). Furthermore, various studies have reported that TGF- $\beta$ is a central mediator of EMT and the inhibition of the TGF- $\beta$ signaling pathway with SB431542 prevented the progression of EMT $(43,44,46)$. These studies support the present findings, which indicated that $\mathrm{c}-\mathrm{Src}$ and TGF- $\beta$ mediate the EMT of LECs.

The present study indicated that PP1 directly inhibited the activity of c-Src and TGF- $\beta$ in HLE-B3 cells following HG stimulation. However, although SB431542 also significantly inhibited the activity of TGF- $\beta$, SB431542 had no significant effect on activity of c-Src. It is likely that PP1 may induce the indirect inhibition on TGF- $\beta$ by the PP1-induced inhibition of c-Src activity. Previous studies have reported that PP1 and PP2 inhibited TGF- $\beta$-mediated cell invasion and migration in pancreatic ductal adenocarcinoma cells and non-small-cell lung carcinoma cells via directly targeting ALK5, suggesting that PP1 and PP2 may be dual inhibitors of TGF- $\beta$ and c-Src in vitro $(47,48)$. This is consistent with the speculations from the present study. Furthermore, incubation with SB431542 resulted in a significant decrease in the protein expression level of TGF- $\beta$ at $6 \mathrm{~h}$, which suggests that SB431542 may affect the cell growth and the cell cycle and promote cell apoptosis of HLE-B3 cells $(49,50)$. The present study has demonstrated 
that PP1 not only restrained the c-Src-induced EMT of LECs, but also downregulated TGF- $\beta$-mediated EMT of LECs. However, it is not known whether c-Src participates in the TGF- $\beta$-mediated EMT of LECs.

In order to further assess the association between c-Src and TGF- $\beta$ and to confirm the inhibiting effect of PP1 on the intracellular function of TGF- $\beta$, shRNA was used to knockdown the c-Src gene in HLE-B3 cells. The results demonstrated that, when phosphorylation of $\mathrm{c}-\mathrm{Src}^{418}$ was inhibited by c-Src gene knockdown, the activities of TGF- $\beta$ and ALK5 were significantly inhibited compared with the shRNA-vector group. This suggests that c-Src may be an upstream molecule that regulates the bioactivity of TGF- $\beta$. In addition, the EMT of HLE-B3 cells was blocked following c-Src knockdown, which indicates that active c-Src may promote the EMT of LECs. It has been reported that the activation of $\mathrm{c}$-Src promoted TGF- $\beta$-mediated EMT of glomerular endothelial cells, in which c-Src is the key regulatory molecule (51). However, studies with regards to c-Src and TGF- $\beta$ have provided various results, including the suggestion that TGF- $\beta$ may regulate the activity of $\mathrm{c}-\mathrm{Src}$ in vascular smooth muscle cells and non-small-cell lung cancer A549 cells $(52,53)$. Maeda et al (46) indicated that Src activation was not involved in the processing of TGF- $\beta$-mediated EMT in mammary epithelial cells and pancreatic ductal adenocarcinoma cells. These different results regarding c-Src and TGF- $\beta$ in the regulation of EMT of various cells may be due to the differences in cell type and stimuli.

In conclusion, the findings of the present study suggest that $\mathrm{c}-\mathrm{Src}$ may be an upstream molecule that regulates the TGF- $\beta$-mediated EMT of LECs under HG conditions. Therefore, the c-Src/TGF- $\beta$ signal axis, particularly c-Src, may be a potential target for preventing and treating complications associated with diabetes mellitus, including diabetic subcapsular cataract. However, further in vitro investigations on the exact mechanism and signaling pathway of c-Src and TGF- $\beta$ are required.

\section{Acknowledgements}

Not applicable.

\section{Funding}

The present study was supported by the grants from the National Natural Science Foundation of China to JZ (grant no. 81370998) and the Innovation Project in Science and Technology of Shaanxi Province to JZ (grant no. 2012KTCQ03-03).

\section{Availability of data and materials}

The datasets used and/or analyzed during the current study are available from the corresponding author on reasonable request.

\section{Authors' contributions}

JZ designed the experiments. $\mathrm{ZHH}$ and $\mathrm{FW}$ performed the experiments. FLW and QL analyzed and interpreted the results of the experiments. QL was a major contributor in writing the manuscript. All authors read and approved the final manuscript.

\section{Ethics approval and consent to participate}

Not applicable.

\section{Patient consent for publication}

Not applicable.

\section{Competing interests}

The authors declare that they have no competing interests.

\section{References}

1. Lang VB, Baretić M and Pavić E: Kidney disease in diabetic patients-the role of family medicine physician. Acta Med Croatica 70: 319-324, 2016 (In Croatian).

2. Campos EJ, Campos A, Martins J and Ambrósio AF: Opening eyes to nanomedicine: Where we are, challenges and expectations on nanotherapy for diabetic retinopathy. Nanomedicine 13: 2101-2113, 2017.

3. Richter GM, Choudhury F, Torres M, Azen SP and Varma R; Los Angeles Latino Eye Study Group: Risk factors for incident cortical, nuclear, posterior subcapsular, and mixed lens opacities: The Los Angeles Latino eye study. Ophthalmology 119: 2040-2047, 2012.

4. Zablocki GJ, Ruzycki PA, Overturf MA, Palla S, Reddy GB and Petrash JM: Aldose reductase-mediated induction of epithelium-to-mesenchymal transition (EMT) in lens. Chem Biol Interact 191: 351-356, 2011.

5. Hegde KR and Varma SD: Cataracts in experimentally diabetic mouse: Morphological and apoptotic changes. Diabetes Obes Metab 7: 200-204, 2005.

6. Cho HG and Yoo J: Rho activation is required for transforming growth factor-beta-induced epithelial-mesenchymal transition in lens epithelial cells. Cell Biol Int 31: 1225-1230, 2007.

7. Struck HG, Heider C and Lautenschläger C: Changes in the lens epithelium of diabetic and non-diabetic patients with various forms of opacities in senile cataract. Klin Monbl Augenheilkd 216: 204-209, 2000 (In German).

8. Deckers M, van Dinther M, Buijs J, Que I, Löwik C, van der Pluijm $G$ and ten Dijke P: The tumor suppressor Smad4 is required for transforming growth factor beta-induced epithelial to mesenchymal transition and bone metastasis of breast cancer cells. Cancer Res 66: 2202-2209, 2006.

9. Valcourt U, Kowanetz M, Niimi H, Heldin CH and Moustakas A: TGF-beta and the Smad signaling pathway support transcriptomic reprogramming during epithelial-mesenchymal cell transition. Mol Biol Cell 16: 1987-2002, 2005.

10. Tsapara A, Luthert P, Greenwood J, Hill CS, Matter K and Balda MS: The RhoA activator GEF-H1/Lfc is a transforming growth factor-beta target gene and effector that regulates alpha-smooth muscle actin expression and cell migration. Mol Biol Cell 21: 860-870, 2010.

11. Sebe A, Leivonen SK, Fintha A, Masszi A, Rosivall L, Kähäri VM and Mucsi I: Transforming growth factor-beta-induced alpha-smooth muscle cell actin expression in renal proximal tubular cells is regulated by p38beta mitogen-activated protein kinase, extracellular signal-regulated protein kinase1,2 and the Smad signalling during epithelial-myofibroblast transdifferentiation. Nephrol Dial Transplant 23: 1537-1545, 2008.

12. Gordon-Thomson C, de Iongh RU, Hales AM, Chamberlain CG and McAvoy JW: Differential cataractogenic potency of TGF-beta1, -beta2, and -beta 3 and their expression in the postnatal rat eye. Invest Ophthalmol Vis Sci 39: 1399-1409, 1998.

13. Hales AM, Chamberlain CG and McAvoy JW: Cataract induction in lenses cultured with transforming growth factor-beta. Invest Ophthalmol Vis Sci 36: 1709-1713, 1995.

14. Liu J, Hales AM, Chamberlain CG and McAvoy JW: Induction of cataract-like changes in rat lens epithelial explants by transforming growth factor beta. Invest Ophthalmol Vis Sci 35: 388-401, 1994

15. Saika S, Kono-Saika S, Ohnishi Y, Sato M, Muragaki Y, Ooshima A, Flanders KC, Yoo J, Anzano M, Liu CY, et al: Smad3 signaling is required for epithelial-mesenchymal transition of lens epithelium after injury. Am J Pathol 164: 651-663, 2004. 
16. Du L, Hao M, Li C, Wu W, Wang W, Ma Z, Yang T, Zhang N, Isaaca AT, Zhu X, et al: Quercetin inhibited epithelial mesenchymal transition in diabetic rats, high-glucose-cultured lens, and SRA01/04 cells through transforming growth factor- $\beta 2 /$ phosphoinositide 3-kinase/Akt pathway. Mol Cell Endocrinol 452: 44-56, 2017.

17. Kim YS, Kim NH, Jung DH, Jang DS, Lee YM, Kim JM and Kim JS: Genistein inhibits aldose reductase activity and high glucose-induced TGF-beta2 expression in human lens epithelial cells. Eur J Pharmacol 594: 18-25, 2008

18. Kim NH, Kim YS, Jung DH and Kim JS: KIOM-79 prevents xylose-induced lens opacity and inhibits TGF-beta 2 in human lens epithelial cells cultured under high glucose. J Ethnopharmacol 130: 599-606, 2010.

19. Lu Q, Yang T, Zhang M, Du L, Liu L, Zhang N, Guo H, Zhang F, $\mathrm{Hu} \mathrm{G}$ and Yin X: Preventative effects of Ginkgo biloba extract (EGb761) on high glucose-cultured opacity of rat lens. Phytother Res 28: 767-773, 2014.

20. MacKay CE and Knock GA: Control of vascular smooth muscle function by Src-family kinases and reactive oxygen species in health and disease. J Physiol 593: 3815-3828, 2015.

21. Hovater MB and Sanders PW: Effect of dietary salt on regulation of TGF- $\beta$ in the kidney. Semin Nephrol 32: 269-276, 2012.

22. Montagner A, Delgado MB, Tallichet-Blanc C, Chan JS, Sng MK, Mottaz H, Degueurce G, Lippi Y, Moret C, Baruchet M, et al: Src is activated by the nuclear receptor peroxisome proliferator-activated receptor $\beta / \delta$ in ultraviolet radiation-induced skin cancer. EMBO Mol Med 6: 80-98, 2014.

23. Tang $\mathrm{CH}$, Hsu CJ, Yang WH and Fong YC: Lipoteichoic acid enhances IL-6 production in human synovial fibroblasts via TLR2 receptor, PKCdelta and c-Src dependent pathways. Biochem Picalharmacol 79: 1648-1657, 2010.

24. Boyer B, Bourgeois Y and Poupon MF: Src kinase contributes to the metastatic spread of carcinoma cells. Oncogene 21: 2347-2356, 2002.

25. Giehl K and Menke A: Microenvironmental regulation of E-cadherin-mediated adherens junctions. Front Biosci 13 3975-3985, 2008.

26. Humar B, Fukuzawa R, Blair V, Dunbier A, More H, Charlton A, Yang HK, Kim WH, Reeve AE, Martin I and Guilford P: Destabilized adhesion in the gastric proliferative zone and c-Src kinase activation mark the development of early diffuse gastric cancer. Cancer Res 67: 2480-2489, 2007.

27. Lawler K, O'Sullivan G, Long A and Kenny D: Shear stress induces internalization of E-cadherin and invasiveness in metastatic oesophageal cancer cells by a Src-dependent pathway. Cancer Sci 100: 1082-1087, 2009.

28. Summy JM and Gallick GE: Src family kinases in tumor progression and metastasis. Cancer Metastasis Rev 22: 337-358, 2003.

29. Elsberger B: Translational evidence on the role of Src kinase and activated Src kinase in invasive breast cancer. Crit Rev Oncol Hematol 89: 343-351, 2014

30. Zhou J and Menko AS: The role of Src family kinases in cortical cataract formation. Invest Ophthalmol Vis Sci 43: 2293-2300, 2002.

31. Zhou J and Menko AS: Coordinate signaling by Src and p38 kinases in the induction of cortical cataract. Invest Ophthalmo Vis Sci 45: 2314-2323, 2004.

32. Walker JL, Wolff IM, Zhang L and Menko AS: Activation of SRC kinases signals induction of posterior capsule opacification. Invest Ophthalmol Vis Sci 48: 2214-2223, 2007.

33. Peng L, Yang J, Ning C, Zhang J, Xiao X, He D, Wang X, Li Z, $\mathrm{Fu} \mathrm{S}$ and Ning J: Rhein inhibits integrin-linked kinase expression and regulates matrix metalloproteinase-9/tissue inhibitor of metalloproteinase-1 ratio in high glucose-induced epithelial-mesenchymal transition of renal tubular cell. Biol Pharm Bull 35: 1676-1685, 2012

34. Gu L, Gao Q, Ni L, Wang M and Shen F: Fasudil inhibits epithelial-myofibroblast transdifferentiation of human renal tubular epithelial HK-2 cells induced by high glucose. Chem Pharm Bull (Tokyo) 61: 688-694, 2013

35. Sutariya B, Jhonsa D and Saraf MN: TGF- $\beta$ : The connecting link between nephropathy and fibrosis. Immunopharmacol Immunotoxicol 38: 39-49. 2016.
36. Wang JY, Gao YB, Zhang N, Zou DW, Wang P, Zhu ZY, Li JY, Zhou SN, Wang SC, Wang YY and Yang JK: miR-21 overexpression enhances TGF- $\beta 1$-induced epithelial-to-mesenchymal transition by target smad7 and aggravates renal damage in diabetic nephropathy. Mol Cell Endocrinol 392: 163-172, 2014.

37. Zhang N, Gao Y, Zou D, Wang J, Li J, Zhou S, Zhu Z, Zhao X, $\mathrm{Xu} \mathrm{L}$ and Zhang $\mathrm{H}$ : Effects of Chinese Medicine Tong xinluo on Diabetic nephropathy via inhibiting TGF- $\beta$ 1-induced epithelial-to-mesenchymal transition. Evid Based Complent Alternat Med 2014: 123497, 2014.

38. Lu Y, Tang L, Li Y and He Q: High glucose-induced fibronectin upregulation in cultured mesangial cells involves caveolin-1-dependent RhoA-GTP activation via Src kinase. Mol Med Rep 14: 963-968. 2016.

39. Sayin N, Kara N and Pekel G: Ocular complications of diabetes mellitus. World J Diabetes 6: 92-108, 2015.

40. Xie X, Lan T, Chang X, Huang K, Huang J, Wang S, Chen C, Shen X, Liu P and Huang H: Connexin43 mediates NF- $\kappa$ B signalling activation induced by high glucose in GMCs: Involvement of c-Src. Cell Commun Signal 11: 38, 2013.

41. Alisson-Silva F, Freire-de-Lima L, Donadio JL, Lucena MC, Penha L, Sá-Diniz JN, Dias WB and Todeschini AR: Increase of O-glycosylated oncofetal fibronectin in high glucose-induced epithelial-mesenchymal transition of cultured human epithelial cells. PLoS One 8: e60471, 2013

42. DeMaio L, Buckley ST, Krishnaveni MS, Flodby P, Dubourd M, Banfalvi A, Xing Y, Ehrhardt C, Minoo P, Zhou B, et al: Ligand-independent transforming growth factor- $\beta$ type I receptor signalling mediates type I collagen-induced epithelial-mesenchymal transition. J Pathol 226: 633-644, 2012.

43. Wilson C, Nicholes K, Bustos D, Lin E, Song Q, Stephan JP, Kirkpatrick DS and Settleman J: Overcoming EMT-associated resistance to anti-cancer drugs via Src/FAK pathway inhibition. Oncotarget 5: 7328-7341, 2014.

44. Lee JY, Chang JW, Yang WS, Kim SB, Park SK, Park JS and Lee SK: Albumin-induced epithelial-mesenchymal transition and ER stress are regulated through a common ROS-c-Src kinase-mTOR pathway: effect of imatinib mesylate. Am J Physiol Renal Physiol 300: F1214-F1222. 2011.

45. Pang L, Li Q, Wei C, Zou H, Li S, Cao W, He J, Zhou Y, Ju X, Lan J, et al: TGF- $\beta 1 /$ Smad signaling pathway regulates epithelial-to-mesenchymal transition in esophageal squamous cell carcinoma: In vitro and clinical analyses of cell lines and nomadic Kazakh patients from northwest Xinjiang, China. PLoS One 9: e112300, 2014

46. Maeda M, Shintani Y, Wheelock MJ and Johnson KR: Src activation is not necessary for transforming growth factor (TGF)-beta-mediated epithelial to mesenchymal transitions (EMT) in mammary epithelial cells. PP1 directly inhibits TGF-beta receptors I and II. J Biol Chem 281: 59-68. 2006.

47. Bartscht T, Lehnert H, Gieseler $F$ and Ungefroren $H$ : The Src family kinase inhibitors PP2 and PP1 effectively block TGF-beta1-induced cell migration and invasion in both established and primary carcinoma cells. Cancer Chemother Pharmacol 70: 221-230, 2012

48. Hoshino Y, Katsuno Y, Ehata S and Miyazono K: Autocrine TGF- $\beta$ protects breast cancer cells from apoptosis through reduction of BH3-only protein, Bim. J Biochem 149: 55-65, 2011.

49. Itoh $\mathrm{S}$ and Itoh $\mathrm{F}$ : Implication of TGF- $\beta$ as a survival factor during tumour development. J Biochem 151: 559-562, 2012.

50. Hovater MB and Sanders PW: Effect of dietary salt on regulation of TGF- $\beta$ in the kindney. Semin Nephrol 32: 269-276, 2012.

51. Deharvengt S, Marmarelis M and Korc M: Concomitant targeting of EGF receptor, TGF-beta and SRC points to a novel therapeutic approach in pancreatic cancer. PLoS One 7: e39684, 2012.

52. Samarakoon R, Chitnis SS, Higgins SP, Higgins CE, Krepinsky JC and Higgins PJ: Redox-induced Src kinase and caveolin-1 signaling in TGF- $\beta 1$-initiated SMAD2/3 activation and PAI-1 expression. PLoS One 6: e22896, 2011.

53. Dong S, Khoo A, Wei J, Bowser RK, Weathington NM, Xiao S, Zhang L, Ma H, Zhao Y and Zhao J: Serum starvation regulates E-cadherin upregulation via activation of c-Src in non-small-cell lung cancer A549 cells. Am J Physiol Cell Physiol 307: C893-C899, 2014. 